\title{
Doktoranci - grupa wybrana czy przegrana? Prezentacja wniosków studium teoretyczno-empirycznego na temat studiów doktoranckich w Polsce
}

STRESZCZENIE. Artykuł prezentuje wnioski z badań dotyczących studiów doktoranckich w Polsce, będących częścią szerzej zakrojonego projektu badawczego na temat kreowania elit społecznych. Celem poznawczym przytaczanych badań był próba opisania i wyjaśnienia faktu społecznego, jakim jest kształcenie elitarne na poziomie wyższym. Z tego powodu należy naszkicować obraz ważnego i dotąd nieopisanego zjawiska na gruncie polskiej edukacji, czyli studiów doktoranckich w ich nowym kształcie. Nieobowiązująca już ustawa o szkolnictwie wyższym z dnia 27 lipca 2005 r. w Dziale IV, w Rozdziale 4 precyzyjnie przedstawiała sposób funkcjonowania studiów doktoranckich, ze szczególnym uwzględnieniem praw i obowiązków doktoranta. Dzięki tym regulacjom przypominały one formalnie studia pierwszego i drugiego stopnia. Różnicowało je zaś coś, co można byłoby nazwać ich „misją”. Doktorant bowiem był potencjalnym kandydatem na pracownika naukowego, mającego być w przyszłości członkiem elity intelektualnej. Posiadał on predyspozycje (intelektualne, interpersonalne, społeczne, emocjonalne, a nawet fizyczne) umożliwiające pracę naukową, będące częścią jego kapitałów - społecznego, kulturowego czy finansowego. Od nich, według badaczy problemu stratyfikacji społecznej, zależał sukces życiowy i uniwersytecki, silnie związany z determinacją, motywacjami, ale też wsparciem osób trzecich (głównie promotora). Od 2011 r., a zatem wraz ze zmianą ustawodawstwa, forma kształcenia na poziomie studiów doktoranckich uległa zmianie. By jak najlepiej scharakteryzować fenomen studiów trzeciego stopnia, biorąc pod uwagę ich wartość i zadania, ale też praktykę uniwersytecką, i - być może - wskazać sposoby udoskonalenia tego modelu studiów, należy zasięgnąć opinii tych, którym analizowana forma kształcenia jest oferowana. Z tego powodu przedmiotem badań zostały identyfikacje i orientacje życiowe grupy 31 doktorantów z różnych polskich uniwersytetów, przedstawiane w wywiadach narracyjnych. Całość wniosków z badań zawiera oddana do druku monografia pt. Kształcenie elit społecznych? Studia doktoranckie w Polsce jako forma i potrzeba konstruowania zapoznanego mitu.

SŁOWA KLUCZOWE: studia doktoranckie, doktorant, studia doktoranckie, elity społeczne, kształcenie elitarne 


\section{Wstęp}

W roku akademickim 2015/2016 na studiach doktoranckich studiowało ponad 40 tys. osób. W zestawieniu ze skalą, jaką znamy sprzed boomu edukacyjnego lat 90., jest to liczba oszałamiająca. Może cieszyć fakt, że tak wielu młodych ludzi (choć nie ma dziś ograniczeń wieku na żadnym ze stopni kształcenia) chce podnosić poziom swojego wykształcenia i zdobywać kolejne szczeble rozwoju naukowego. Głosy zabierane w publicznej debacie wskazują jednak, że więcej jest w tym zjawisku ciemnych stron, takich jak dewaluacja dyplomów magisterskich, masowość kształcenia, brak autentycznej relacji mistrza i ucznia. Doktoranci nie jawią się już jako przyszła, czy choćby potencjalna, klasa czy elita intelektualna, ale co najwyżej - jak twierdzi Thomas H. Davenport (2007) - pracownicy wiedzy.

W polskich realiach sytuację doktorantów w związku z przemianami funkcji uniwersytetu i budowania nowego społeczeństwa wiedzy opisał za pomocą podobnej kategorii Tomasz Szkudlarek (2012)․․ Badacz nazywa tę grupę, odwołując się do tradycji marksowskiej, nowymi „robotnikami wiedzy”, funkcjonującymi w specyficznie określonym środowisku, tj. w/wokół Akademii. Jest to jedna z perspektyw, jaką można przyjąć, interpretując uniwersytecką rzeczywistość. Szkudlarek pisze o niej w następujący sposób:

Sądzę, że w przypadku ideologii społeczeństwa wiedzy, mamy do czynienia z tego rodzaju przesłonięciem przez banalizację bardzo istotnego, ale zarazem nader rzadko poddawanego dyskusji wymiaru naczelnej jej kategorii: bardzo chętnie pomijamy fakt, że cały czas mówi się tak o kapitalistycznym społeczeństwie wiedzy; że wiedza ma w tej doktrynie charakter ka pitału i powstaje jako kapitał w procesie produkcji towarowej (Szkudlarek 2012: 220).

W mediach natomiast doktoranci najczęściej przedstawiani są jako osoby, które chcą przedłużyć sobie okres studiów czy nieudacznicy życiowi, nie zaś jako osoby pretendujące do nagród Nobla.

${ }^{1}$ Doktoranci w tekście Tomasza Szkudlarka są jedynie egzemplifikacją przemian, jakie zachodzą w Akademii funkcjonującej w globalnym świecie, zbudowanym na neoliberalnej ideologii zysku, kapitału i dominacji. Szkudlarek, przedstawiając tezy do analiz zawartych w tekście, pisze: „Spójrzmy zatem na "nowy uniwersytet « przez pryzmat logiki kapitalistycznego społeczeństwa wiedzy i przyjrzyjmy się kilku jego aspektom. Po pierwsze, jak zapowiadałem, zastanowimy się nad tym, co w procesie konstruowania tej nowej formy społecznej totalności/tożsamości podlega wykluczeniu. Podejmiemy więc kwestię ig n or an cji jako »cienia« wiedzy i strukturalnego warunku uczynienia z niej hegemonicznej logiki systemu. W związku z tym zagadnieniem zwrócimy uwagę na kilka znanych już i często w publicystyce zauważanych wymiarów parcelacji wiedzy, jej prywatyzacji i »grodzenia« wykluczającego większość ludzi ze swobodnego dostępu do rezultatów badań. Po trzecie, przyjrzymy się »nowemu proletariatowi« - ro b ot ni ko m wi ed zy” (Szkudlarek 2012: 223). 
Jak te opinie mają się do rzeczywistości, a szczególnie co sądzą o studiach doktoranckich sami doktoranci? Dlaczego podejmują trud, nie zawsze zakończony obroną doktoratu², i zostają studentami studiów trzeciego stopnia? Jakie są ich motywacje, plany, oczekiwania, ale też marzenia czy wartości? Czy uniwersytet jako „wieża z kości słoniowej”, kierująca się swoistym etosem akademickim i kulturotwórczą misją, wciąż jest „ich miejscem”, wartością, która kształtuje wybory życiowe? Uznałam, że warto poznać odpowiedzi na te pytania, odwołując się do sytuacji życiowej doktorantów, ich statusu materialnego czy posiadanych kapitałów (ekonomicznego, społecznego, kulturowego). Pytania te stały się pretekstem i powodem badań, jakie przeprowadziłam w latach 2010-2013 w Polsce oraz na najlepszych uniwersytetach świata (m.in. Harvard University, Oxford University, Peking University). Niniejsze badania doktorantów są częścią większego projektu dotyczącego kształcenia elit społecznych na świecie oraz kreowania zmian spolecznych. Mieszczą się w nim różnorodne wątki porównawcze i kulturowe, takie jak prowadzenie studiów doktoranckich, relacja mistrz - uczeń i jej historia, jakość kształcenia, struktura społeczna i jej determinanty3.

Prezentowany artykuł ma przedstawić założenia przeprowadzonych badań oraz omówić najważniejsze wnioski z analiz bazujących na badaniach ${ }^{4}$. Jest to zatem swoisty i znacznie skrócony raport z badań, jednak bez zawartych w książce rekomendacji i wniosków praktycznych, które mogłyby stać się podstawą zmian kształcenia doktorantów w Polsce.

\section{Założenia teoretyczne projektu badawczego "Studia doktoranckie w Polsce"}

Badania, jakie przytaczam w niniejszym tekście, są szerzej opisane i zanalizowane w oddanej do druku publikacji mojego autorstwa pt. Ksztatcenie elit spolecznych? Studia doktoranckie $w$ Polsce jako forma i potrzeba konstruowania zapoznanego mitu. Dotyczą studiów doktoranckich w Polsce i zostały przeprowadzone w związku

${ }^{2}$ Według danych Głównego Urzędu Statystycznego w 2015 r. nadano ogółem w Polsce 5956 stopni doktora, w tym 3169 stopni przyznano kobietom (GUS 2016: 168). Dla porównania należy przypomnieć, że liczba uczestników studiów doktoranckich w ostatnich latach sukcesywnie rosła. W roku akademickim 2011/2012 przekroczyła ona liczbę 40 tys.

${ }^{3}$ Wymienione wątki będą rozwijane w kolejnych publikacjach poświęconych studiom doktoranckim w perspektywie porównawczej.

${ }^{4}$ Stąd nie można powiedzieć, że książka przypomina np. opracowany w 2015 r. raport Najwyższej Izby Kontroli dotyczący kształcenia na studiach doktoranckich. „Celem głównym kontroli była ocena skuteczności stacjonarnych studiów doktoranckich jako drogi kształcenia kadr naukowych ze środków publicznych. Ocena dotyczyła w szczególności: 1) warunków kształcenia doktorantów, 2) prawidłowości wykorzystania środków finansowych na rozwój i kształcenie doktorantów, 3) skuteczności kształcenia kadr naukowych" (NIK 2015: 5). 
z przygotowywaną rozprawą doktorską obronioną w grudniu 2011 r. pod kierunkiem prof. Zbigniewa Kwiecińskiego ${ }^{5}$. Celem badań była próba opisania i wyjaśnienia faktu społecznego, jakim jest kształcenie elitarne na poziomie wyższym, czyli studiów doktoranckich w ich nowej formie, regulowanych przez ustawę o szkolnictwie wyższym z dnia 27 lipca 2005 r. Dzięki tym przepisom, przypominają one formalnie studia pierwszego i drugiego stopnia (są wszakże studiami trzeciego stopnia) $)^{6}$.

Przeprowadzone i omawiane tu badania miały pomóc w odpowiedzi na pytanie: Czy i w jakim zakresie studia doktoranckie kształcą przyszłych członków elit, kształtujących najważniejsze w kraju procesy społeczne, kulturalne i polityczne? Jest to kwestia o tyle ważna, że przemiany uniwersytetu w kraju i za granicą, które zachodzą w wyniku takich procesów, jak utowarowienie wykształcenia, merkantylizacja, kredencjalizm czy innych związanych z globalizacją, mają znaczenie dla autoidentyfikacji zarówno pracowników naukowych, jak i studentów, ale też samych uniwersytetów?

Wydaje się też, że z kolei charakterystyczny dla ponowoczesności pluralizm w tym wypadku motywacji, dróg życiowych, ścieżek edukacyjnych, ale także późniejszej kariery doktorantów - dodatkowo wzmaga ambiwalentny charakter studiów doktoranckich. Doktoranci są (byli) kształceni, by w przyszłości zostać pracownikami nauki. Nie zawsze w edukacji doktorantów jest zaś obecna świadomość innych możliwości kariery: w biznesie, polityce, samorządzie czy w instytucjach kultury. Jest jednak kwestią nie do podważenia, że każde państwo potrzebuje różnego typu elit i to na każdym szczeblu: krajowym, regionalnym i lokalnym. Dlatego warto sobie zadać pytanie, jakie wartości są bliskie przyszłym elitom oraz jaki wpływ na nie ma kształcenie uniwersyteckie?

Nie można jednakże właściwie sformułować problemu badawczego bez wyznaczenia teoretycznej ramy odniesienia, bez szczegółowych pojęć pomagających właś-

\footnotetext{
${ }^{5}$ Rozprawa doktorska nosiła tytuł Problemy kształcenia elit. Przypadek studiów doktoranckich $w$ Polsce.

${ }^{6}$ Zdaję sobie sprawę z faktu, że z dniem 1 października 2011 r. cytowana ustawa przestała obowiązywać w ówczesnym kształcie, ale badania prowadzone na potrzeby rozprawy toczyły się, gdy obowiązywało jeszcze poprzednie prawo o szkolnictwie wyższym, choć pewne rozwiązania pochodzily z ustawy z dnia 12 września 1990 r. Prawo o szkolnictwie wyższym. Ma to znaczenie dla badań, bowiem w efekcie okazuje się, że badani odbywają studia, których ksztalt regulowany jest przez trzy różne ustawy, co może wpływać na ich ocenę systemu szkolnictwa wyższego i studiów doktoranckich, ale także przekłada się na codzienność i praktykę studiowania.

7 Jest to pytanie wciąż ważne i aktualne, szczególnie w kontekście toczącej się w latach 2016-2017 publicznej debaty angażującej środowisko akademickie, ale też szerzej - bo także opinię publiczną w związku z konstruowaniem nowej ustawy regulującej funkcjonowanie uczelni wyższych i nauki w Polsce. Są to działania w formie projektów ustaw, ale też cykliczne konferencje, poświęcone różnym tematom dotyczącym Akademii, które gromadzą ekspertów, badaczy, osoby sprawujące władzę nad uczelniami i innymi jednostkami naukowymi.
} 
ciwie ująć problem badawczy. Pierwszym z nich jest „elita społeczna”. Drugi stanowi „kształcenie elitarne”, wpisane w kontekst - z jednej strony realiów polskich, a z drugiej zaś - globalnego świata, określającego cele i wartości edukacji.

Omawiając definicje elit społecznych, za Markiem Żyromskim (2007: 7), należy zwrócić uwagę, że nie można mówić o jednej spójnej teorii elit, ale raczej o teoriach elit, konstytuowanych z punktu widzenia promowanych i podkreślanych aspektów (np. władza, posiadany majątek, walory intelektualne), ale też pisanych z perspektywy odmiennych dziedzin nauki (politologia, socjologia, pedagogika). Ponadto jest to zjawisko, którego definicja jest wyraźnie waloryzowana, zarówno w literaturze socjologiczno-politologiczno-pedagogicznej ${ }^{8}$, jak i w ramach wiedzy potocznej. Pojawiają się zatem definicje elit społecznych o charakterze konserwatywnym, ale też egalitarystycznym, jak i te nawiązujące do etymologii słowa „elita”.

Poza definicjami należy przywołać najważniejsze teorie elit, np. Charlesa Wrighta Millsa (1961), która zestawiona jest z koncepcją „kapitału społecznego” w rozumieniu Pierre'a Bourdieu i Jean-Claude'a Passerona (1990) czy Francisa Fukuyamy (2009), czy teoria elit Vilfreda Pareto (1994). Omawianie współczesnych teorii elit warto jednakże wpisać w kontekst współczesności, używając ważnych z tej perspektywy kategorii, takich jak wspólne dobro czy wspólnotowość (tym samym nawiązując do myśli komunitariańskiej), innowacyjność, społeczeństwo obywatelskie (analizując je w kontekście przemian społecznych i politycznych mających miejsce w Polsce przed 1989 r. i po nim), zaangażowanie społeczne. Stąd pojawia się w pracy także odmienne wobec cytowanych wyżej autorów rozumienie „kapitału społecznego" w ujęciu Roberta Putnama (2008), bazujące na pojęciu wzajemnego zaufania - do innych obywateli, ale też do władz i instytucji.

W swoich badaniach odnoszę się zatem do problemów kształcenia elit, koncentrując się na trzech wątkach: (1) egalitarystycznym (realnym bądź jedynie pozornym) charakterze polskiej edukacji, (2) nieobecności analiz dotyczących kształcenia elitarnego (być może ze względu na niewypracowanie definicji tego rodzaju kształcenia), a także na (3) próbie ukucia takiej właśnie definicji. Odrębne wobec powyższych kwestii jest przywołanie instytucji kształcenia na poziomie wyższym, które mogłyby zostać nazwane „elitarnymi”. Są wśród nich Międzywydziałowe Indywidualne Studia Humanistyczne (MISH), Akademia Artes Liberales, kształcąca podyplomowo Krajowa Szkoła Administracji Publicznej czy Stowarzyszenie Szkoła Liderów 9 .

${ }^{8} \mathrm{~W}$ obszarze myśli pedagogicznej najmniej jest analiz dotyczących elit społecznych.

9 We wspomnianym opisie zawarta jest jasna intencja zbudowania meliorystycznej definicji elit, która może być odczytywana jako zbudowanie nowego etosu elit, który będzie inkluzyjny, a jednocześnie będzie promował ideę wprowadzenia do instytucji społecznych zrównoważonego rozwoju w wymiarach jednostkowym i wspólnotowym. Zgodnie z takim myśleniem uniwersytet, a szczególnie studia doktoranckie, powinien kształcić nie tylko intelektualistów - akademików, ale także członków elit społecznych w szerokim rozumieniu. Doktorat nie musi dziś prowadzić do kariery naukowej, a tym 


\section{Cele i organizacja badań własnych}

Celem podjętego badania była próba opisania i wyjaśnienia faktu społecznego, jakim jest edukacja elitarna na poziomie wyższym. Dodatkowy cel badania stanowiła próba określenia i wyodrębnienia typów współczesnych doktorantów. W konsekwencji przedmiotem badań uczyniono orientacje życiowe grupy 31 badanych doktorantów oraz ich deklaracje dotyczące identyfikacji z elitą, uniwersytetem oraz studiami doktoranckimi. Badane osoby pochodziły z różnych środowisk, co powodowało, że posiadają inny kapitał społeczny i symboliczny (a także ekonomiczny). Mieszkały głównie w dużych miastach akademickich, ale często ich miejsce urodzenia było zupełnie inne (część osób wychowała się na wsi). Założeniem konstrukcyjnym próby badawczej było porównanie form studiowania na trzech uniwersytetach w Polsce. Pierwszym z nich był Uniwersytet Warszawski, będący jedną z dwóch najlepszych uczelni w kraju. Drugim był Uniwersytet Wrocławski, funkcjonujący w specyficznym otoczeniu. Jest to miasto blisko granicy z Czechami i Niemcami, które po 1945 r. buduje swoją polską tożsamość i lokalne elity intelektualne. Trzecią uczelnią, której doktoranci wzięli udział w badaniach, jest Uniwersytet Mikołaja Kopernika w Toruniu. Jest to z kolei jednostka funkcjonująca w specyficznych ekonomicznych warunkach - z małym, wolno rozwijającym się rynkiem pracy ${ }^{10}$.

W próbie badawczej znaleźli się reprezentanci różnych dyscyplin naukowych. Próba była w tym względzie tak zróżnicowana, że nie można wskazać na dominację jakiegoś obszaru. Inne kryteria (np. płeć, wiek) też nie okazały się tu wartościujące czy niuansujące. Badanie miało pokazać bowiem, czy strategie studiowania są na tyle oryginalne, zindywidualizowane i wyjątkowe, by móc je nazwać elitarnymi.

Przeprowadzone badania opierały się na dwóch perspektywach badawczych: biograficznej, reprezentowanej przez Fritza Schützego (1997) i Pierre'a Dominicé (2006), oraz instytucjonalnej, której założenia pochodzą od Pierre’a Bourdieu i Jean-Claude’a Passerona (1990). Dobór perspektywy miał przełożenie na wybór metody badawczej, którą stanowią studium przypadku oraz metoda biograficzna. Są one zaś wsparte dodatkowymi teoriami (biografia edukacyjna, narracyjność,

\footnotetext{
bardziej jej nie gwarantuje. Studia pierwszego i drugiego stopnia zgodnie z deklaracją bolońską muszą mieć charakter bardziej zawodowy, m.in. uczyć studentów funkcjonowania na rynku pracy, który staje się coraz bardziej globalny, a w związku z tym niestabilny i kierowany często przez przypadek. Dlaczego zatem nie uczynić takimi studiów trzeciego stopnia? Chodzi bowiem o to, by z grup absolwentów studiów doktoranckich rekrutowali się członkowie elit gospodarczych czy politycznych oraz by w tych grupach znaleźli się eksperci, czyli osoby przygotowywane i kształcone do pełnienia ważnych ról w państwie.

${ }^{10} \mathrm{~W}$ próbie badawczej znalazły się też przypadki osób studiujących w innych uczelniach, lecz znaczenie tego faktu jest znikome, szczególnie że, jak się okazało, uczelnia nie jest czynnikiem różnicującym.
} 
konstruktywizm) i perspektywami interpretacyjnymi. Wszystko to sprawia, że $\mathrm{w}$ przeprowadzonych badaniach doszło do triangulacji metodologicznej oraz triangulacji danych (Rubacha 2008: 88), czyli użyto więcej niż jednej metody i teorii. W badaniach wykorzystano metodę wywiadu pogłębionego z zestandaryzowaną listą pytań. Przeprowadzono 31 wywiadów, które odbyły się w Warszawie, Toruniu i we Wrocławiu pomiędzy styczniem a lipcem $2010 \mathrm{r}$.

W kontekście przedstawionych poniżej wniosków z badań mogą pojawić się jednak głosy krytyczne, wskazujące, że badania prowadzone metodą porównawczego studium przypadku są zbyt mało porównawcze. Wydaje się, że dysponując tak bogatym materiałem badawczym (ponad 400 stron tekstu wywiadów) i - w konsekwencji - bogatym w problemy opracowaniem tego materiału, nie zawsze można skupić się na wątkach stricte biograficznych. Biograficzność stanowi jedynie pomocniczą perspektywę analityczną i badawczą, która nie powinna dominować w pracy poświęconej problemowi studiów doktoranckich per se. Wątki biograficzne są jednak obecne w książce, np. w opisie motywacji podjęcia studiów trzeciego stopnia czy w analizie statusu społecznego, jaki reprezentują badani. Zbierając materiał badawczy, miałam nadzieję, że można przeprowadzić porównanie ścieżek edukacyjnych doktorantów różnych uczelni. Jak się okazało, uczelnia nie była w badaniu czynnikiem różnicującym, podobnie jak nie były nimi: status społeczny, kierunek studiów czy płeć. Świadczy to o wyjątkowym indywidualizmie biografii badanych osób, które być może warto byłoby opisać w sposób jednostkowy, nie zaś przekrojowy.

Inną wątpliwość budzi kwestia wspólnoty doświadczeń z osobami badanymi, która występuje ze względu na wypełnianie tej samej roli, co osoby badane, czyli bycie doktorantem. Ta oczywista jednolitość perspektyw mogły sprawić, że pewne treści przeoczono, nie uwypuklono, bowiem zostały przeze mnie (jako badaczkę) uznane za jawne i oczywiste dla wszystkich. Jednak widzę tę wspólną perspektywę jako pewien za sób, który z jednej strony pozwala mi lepiej (z)rozumieć to, co doktoranci myślą, mówią i jakie decyzje podejmują. Mnie przecież dotyczyły te same problemy czy trudności, które łatwiej mi było zidentyfikować i nazwać.

\section{Wnioski z badań}

Do najważniejszych wniosków, które płyną z przeprowadzonych przeze mnie badań, zaliczam: wskazanie, że (1) zapoczątkowanie procesu e galitaryzacji studiów doktoranckich wpływa przede wszystkim na upowszechnienie studiów wyższych oraz zmianę profilu samych studiów, które zgodnie z deklaracją bolońską mają stać się dostępne dla coraz większej liczby osób. Jak mówi jeden z respondentów:

Rodzice nie mają wykształcenia wyższego, także ja no właściwie jako pierwszy z tej naszej rodziny mam wyższe wykształcenie i poszedłem na 
studia doktoranckie, także to jakoś by obalało tezę o reprodukcji, tym bardziej, już na boku, że znam wiele osób, których rodzice maja wyższe wykształcenie czy sq pracownikami naukowymi i albo maja problemy ze skończeniem studiów, albo nie dostają się na studia doktoranckie. Jeżeli, na pewno jest jakaś korela cja, ale z moich obserwacji, nie prowadząc badań, jest ona niewielka [D28].

Doktoranci pochodzą z różnych środowisk i warstw społecznych, jednak edukacja sprawia, że mają możliwość ubiegania się o bycie członkiem elity społecznej. Jednakże powoduje to (2) powstanie n ow e go eto su in teligenta. Respondentka podsumowuje to, nawiązując do teorii i koncepcji Anthony'ego Giddensa:

Na pewno odczuwam jakąś misję i myślę, że bardziej, ale to też nie jest tė̇ taki klasyczny etos inteligenta, to jest raczej takie poczucie, żeby poddawać to wszystko ciągłej refleksji, Giddens wyjeżdża różnymi stronami, ale chyba się tego nie da inaczej zrobić po prostu [D1].

Tym, co różni inteligentów od klasy średniej, wyróżnionej ze względu na status ekonomiczny, jest właśnie wiedza i świadomość procesów społecznych. Respondentka z Uniwersytetu Wrocławskiego opowiada o decyzjach swoich dobrze uposażonych rodziców, którzy nieumiejętnie i bez wyraźnego kierunku wytyczają ścieżkę edukacyjną swojej córki. Doktorantka przywołuje takie oto wydarzenia:

Ale to jest taka specyficzna rodzina, bo ona jest taka z awansu powiedzmy. Moja mat$k a$ odpowiednim momencie wbiła się $w$ temat biznesowy, także pieniądze $w$ mojej rodzinie nigdy nie odgrywały jakiejś, nie byly wielkim problemem. One byly, tylko były z takim, jak to teraz używając żargonu socjologicznego, no gorzej było z takim kapitatem kulturowo-społecznym, prawda? Wiedziano, że dzieci powinny się uczyć, ale tak nie wiadomo byto, $w$ co inwestow ać, tak? Patrzę teraz jakby na moich rówieśników, którzy, nie wiem, od początku uczyli się francuskiego, angielskiego, niemieckiego i wszystkiego naraz po prostu, a jeszcze do tego skończyli szkote muzyczna i chodzili na warsztaty plastyczne, to ja żadnej z tych rzeczy nie miatam. Poza tym to, że pochodzę z takiego miasteczka, a nie innego, moi rówieśnicy, czasem nie byto ich stać na to, więc jak mnie matka zapisywała na przyklad na angielski, to ja nie chciałam chodzić na ten angielski, bo żadna z moich koleżanek z klasy z podstawówki nie chodzita i dla mnie to bylo obciachowe po prostu [D25].

Wskazywać to może na fakt, że kapitał ekonomiczny w zestawieniu z kapitałem społecznym i kulturowym ma drugorzędne znaczenie dla wyborów związanych $\mathrm{z}$ edukacją. Ważniejsza jest $\mathrm{w}$ tym względzie wiedza na temat trendów rozwojowych, znajomości rynku pracy czy systemów kształcenia.

Doktoranci mówią też o (3) wyjątkowo niskiej ocenie tytułu magisterskiego, który przyczynia się do podejmowania studiów doktoranckich. Za ten stan odpowiada przede wszystkim proces boloński, wobec którego przeciwni są sami studenci, doktoranci, a także profesorowie. Jest to o tyle ważna konstatacja, że w tym działaniu widać właściwie jedyny e m a n cyp a cyjn y wymiar studiów doktoranckich. 
W opowieści respondentki wszystkie grupy (studencka, doktorancka, pracowników naukowych) jednoczą się, by stawiać założeniom i konsekwencjom procesu bolońskiego zinstytucjonalizowany opór.

Znaczy u nas, ja się śmieję, mamy w ogóle taka grupę jakby, i tak to jest takim punktem, mamy silna grupę oporu z procesu bolońskiego rzeczywiście [D1].

Przemiany studiów doktoranckich cechuje (4) pozorność i schematyczn o ść, które w zamierzeniu miały być progiem kariery naukowej, rozpatrywanej zarówno w wymiarze ideowym (czyli jako działania poszerzające horyzonty myślowe, uczące krytyki, ale też odwagi w pracach badawczych), jak i praktycznym (uczące, jak przygotować i zrealizować projekt badawczy). Ocena studiów doktoranckich musi być zatem negatywna:

A $w$ praktyce to te studia doktoranckie, które miały być jakimś rozwijaniem horyzontów, perspektyw, umożliwieniem jakichś badań, nie wiem, wyjazdów na różne staże, nie wiem, różnych stypendiach, to niestety ta idea spełzła, moim zdaniem, na niczym, bo z moich rozmów z niższymi rocznikami wynika, że tak naprawdę, że zamiast się zając czytaniem jakimś, robieniem jakiejś kwerendy, czy tam nie wiem, jeżdżeniem na konferencje, to muszą biegać na przedmioty, które są wymyślone odgórnie, które mają niewiele wspólnego z ich zainteresowaniami i na przykład wiem, że strasznie właśnie marudzą, że mają jakieś zajęcia z informatyki, na których się nic nie uczq nowego, może poza tym, jak tam edy tować teksty $w$ Wordzie, albo maja jakieś zajęcia z dydaktyki z filozofii, albo jakieś inne [D18].

Rezultat tego stanu jest taki, że (5) doktoranci nie oceniają wysoko swojej pracy wykonywanej w ramach studiów. Przy czym na różne sposoby ocenia się „przydatność” studiów humanistycznych i ścisłych, czy technicznych, które pozwalają na karierę na innej niż naukowa ścieżce. W przypadku nauk ścisłych czy technicznych doktorat może pomóc w rozwoju, podnosi kwalifikacje i jest dodatkowym atutem, na równi np. z ukończonymi studiami podyplomowymi czy kursami specjalizacyjnymi. Z tego względu studia doktoranckie jawią się jako:

[...] enklawa to może nie, ale taka trochę nisza jednak mimo wszystko [D1].

To powoduje, że niektórzy oceniają studia jako zbędne i bezcelowe:

I trochę jest trudno wyobrazić mi sobie miejsce, gdzie byśmy byli jakoś bardzo potrzebni [D1].

Wiąże się z tym swoista (6) a utoteliczność studiów doktoranckich tak widoczna na studiach humanistycznych, na których na wszystkich poziomach nauczania uniwersyteckiego studiuje dziś znacznie więcej - w porównaniu ze studiami ścisłymi - osób. Potwierdza to analiza motywacji stojących za decyzją o podjęciu studiów doktoranckich, wśród których dominujące są te o charakterze wewnętrz- 
nym, bazujące na potrzebach intelektualnego rozwoju, samorealizacji, potrzebach poznawczych.

Najczęściej jednak wymienianymi powodami podjęcia studiów doktoranckich są zainteresowania oraz ciekawość poznawcza, zauważana od początku całej ścieżki edukacyjnej.

Chociaż myślę, że decydują się ludzie, przynajmniej na naszym kierunku, którzy się naprawdę tym interesują, którzy się chca rozwijać sami dla siebie, bezjakichśs specjalnych, bez takiego założenia, że coś im to da kiedyś w życiu, wręcz odwrotnie [D1].

Łączy się z nimi inna motywacja o charakterze wewnętrznym - ambicja, co doktorantka deklaruje wprost:

Myślę, że dużo ludzi ci to powie, ale wydaje mi się - ambicja [D1].

Nie ma natomiast w wypowiedziach przebadanych osób motywacji zewnętrznych, wynikających z konieczności podniesienia kwalifikacji zawodowych, rywalizacji czy obowiązku służbowego (np. związanego z koniecznością zdobycia tytułu doktora przez asystentów zatrudnionych na uczelniach).

Zauważalny jest także (7) konflikt ról, jaki deklarują respondenci. Nie dotyczy on jednak przewidywanej rozbieżności w traktowaniu siebie jako studenta, albo pracownika, ale dotyczy konfliktu między zajęciami uczelnianymi a pracą zawodową podejmowaną poza nią. Praca ta ma charakter nie tyle rozwijający, ile zarobkowy. Nie jest zatem podejmowana z powodów ambicjonalnych, lecz finansowych. Wpływa to zdecydowanie negatywnie na obraz swojej osoby. Doktorantka wymienia trudności:

Mój patron ostatnio mnie poinformowat, że oczywiście aplikacja jest najważniejsza i ja tutaj pozostaje $w$ nieustannym konflikcie pomiędzy doktoratem a aplikacja, ponieważ $w$ kancelarii czuję nacisk, że kiedy już zacznę pracować na peten etat, teraz na razie mam tylko taka praktykę, jestem z doskoku, to się odbija na bardzo mizernym wynagrodzeniu, ale nie jestem jeszcze tak oblożona, kiedy zaczna aplikację, zajęcia, dostaję umowę i oczywiście zasady są bez zmian [D5].

Niektórzy boją się tego tak bardzo, że nie przyznają się publicznie do bycia uczestnikiem studiów doktoranckich, a nawet proszą swoich promotorów o publiczne niepodejmowanie tematu ich doktoratu i opieki promotorskiej.

Znałam dziewczynę od nas, która się boi przyznać w pracy, że studiuje i za każdym razem jak wychodzi, to coś wymyśla, że idzie do lekarza, albo gdzieś, jeśli musi wyjść wcześniej, bo... A pracuje $w$ ambasadzie, $w$ jednej z ambasad. Powiedziała, że po prostu miałaby o wiele trudniej $w$ pracy, gdyby powiedziała, że jest doktorantka, bo jak szukata pracy, to taka informacja, że jest, jakby zniechęcata pracodawcę [D1]. 
Czymś, co może zaskakiwać w wypowiedziach respondentów, jest (8) fakt nieposiadania autorytetów, mistrzów, nauczycieli, osób znaczących, ważących na wyborach edukacyjnych czy życiowych. Być może wynika to z panującej obecnie kultury indywidualizmu, nowoczesnej potrzeby oryginalności, kulcie nowości, niepozwalającym na publiczne wyznania o wzorowaniu się na innych, albo ze zmiany kryteriów bycia autorytetem.

Nie wiem [co to jest „szkoła naukowa” - A.M.K.]. Nigdy nikt nie byt dla mnie autory tetem, mistrzem. O nikim bym nie mogła w taki sposób powiedzieć. Jakkolwiek bym go cenita. Jest dużo osób, które cenię za wiedzę, sposób podejścia do życia, ale nie tak, żeby zagapiać się na niego i robić wszystko $w$ taki sam sposób jak on [D6].

W przypadku doktorantów decyzja o wyborze określonego uniwersytetu najczęściej powodowana jest miejscem, gdzie dana osoba ukończyła studia magisterskie. Świadczy to o (9) niskim poziomie mobilności w zakresie wyboru uczelni, na której podejmuje się studia doktoranckie. Jednak (10) wybór uczelni w większości badanych przypadków ma charakter prag maty czny i instrumentalny, nie wynika zaś z analiz rankingów szkół wyższych, czy intelektualnego potencjału uczelni i osób tam zatrudnionych. Doktoranci (11) podważają wartość i znaczenie rankingów. Wybory miejsca studiowania zwykle związane są z kosztami utrzymania, szacowanymi dla określonego miasta uniwersyteckiego.

Doktorantów dotyczy także inna kwestia, a mianowicie (12) niski poziom mobilności w zakresie wyboru kierunku studiów, a także (13) niska mobilność międzynarodowa. Nie można też mówić już o (14) procesach selekcyjnych, dzielących społeczności względem posiadania pewnych kapitałów. Dziś o sukcesie w większym stopniu decyduje przypadek, szczęście, los, co sprawia, że ludzkie życie nabiera nieprzewidywalnego charakteru. Ponadto wyjątkowość i wybitność cech intelektualnych czy wiedza doktoranta nie wpływają na późniejsze możliwości znalezienia pracy.

Dlatego należy w tym miejscu powiedzieć o mechanizmie społecznym dotyczącym studiów doktoranckich i jego uczestników, czyli o (15) odroczonej selekcji. Idea systemu bolońskiego, a także kierunki rozwoju Unii Europejskiej sprawiają, że studia (także te trzeciego stopnia) stają się coraz bardziej powszechne. Konieczne zatem stało się obniżenie kryteriów doboru, by móc w swoje struktury włączyć jak najwięcej osób. Przyjmuje się na nie tylu studentów, ilu można zapewnić warunki pobierania nauki (np. system stypendialny obejmujący także stypendia pomocy materialnej, możliwość uczestnictwa w zajęciach, badaniach). Eliminuje się w ten sposób selekcję i dobór tych, którzy będą realizować zadania uniwersytetu - prowadzić badania, uczyć studentów oraz dbać o rozwój społeczny. Nie znaczy to jednak, że ta funkcja zanikła. Została ona odroczona na etap po zakoń- 
czeniu studiów, chociaż sama obrona doktoratu i proces jego pisania jest już tu czynnikiem selekcji i eliminacji. Należy bowiem mieć silną determinację i wysoką motywację wewnętrzną, by podjąc studia niegwarantujące sukcesu naukowego ani zawodowego. Stąd może w przypadku badania motywacji podjęcia studiów doktoranckich przeważają te o charakterze osobistym, wewnętrznym: własne zainteresowania czy ambicje, mające charakter stricte autoteliczny. Jest to objaw egalitaryzacji studiów doktoranckich, które odbywają się w elitarnej in stytu cji. Pozwala ona na kształcenie masowe, jednak funkcja badawcza (przejawiająca się np. w zatrudnianiu właściwych osób) pozostaje wciąż elitarna i opiera się na głębokiej i złożonej selekcji, na którą wpływ ma wiele czynników, nie tylko możliwości intelektualne jednostki.

Wydaje się, że w słowniku badanych doktorantów pojęcie elity - zarówno społecznej, jak wąsko pojmowanej: intelektualnej - nie istnieje. Zdecydowanie częściej niż o elitach i elitarności mówią oni o prestiżu. Elitarność wiąże się z posiadaniem zasad, kierowaniem się w życiu określonymi ideałami, mogącymi pozostawać w sprzeczności z tym, co głoszą inni. Jest to zatem forma uczciwości wobec siebie, nonkonformizm, czasem zaś - pozostawanie w konflikcie z innymi. Od członków elit wymaga się jednak akceptacji odmienności i posiadania własnego zdania.

Można zatem powiedzieć, że elitarność w opinii przebadanych doktorantów jest cechą stricte (1) jednostkową, nie zaś związaną z określoną grupą społeczną. Członkowie elit m.in. wiedzą i rozumieją więcej, a więc posiadają (2) cechy intelektualne pozwalające im widzieć rzeczywistość w sposób nieschematyczny, szerszy, a także dostrzegać „drugie dno”. Jest to pewien (4) zasób jed nostki, mogący być pomnażany albo bezwiednie niewykorzystywany. Elitarność może być również (5) wzo rcem zachowań, a więc sposobem działania, normą, (6) określonym dla relacji - mogącej mieć charakter interpersonalny, ale też dotyczący zbiorowości. Wzorzec ten powinien być społecznie (7) wartościowany pozytywnie i to (8) w sposób niekwestionowany. Elitarność rozumiana jest jako inteligencja: (9) społeczna i (10) emocjonalna. Elitarność może być pojmowanajako (11) wrażliwość s połeczna, ale też(12) podawanie w wątpliwość zastanego porządku. Dzieje się to w sprzeczności z cechami, które na elitę nakładają zadanie podtrzymywania struktury społecznej. Innymi słowy, jest to rzadki (a więc elitarny), jak stwierdza respondentka, (16) rodzaj szacunku do innych i (17) otwartości na nich. Ważne jest także posiadanie (18) u miejętności właściwego wykorzystania tych walorów.

\section{Konkluzje}

Wnioski z przeprowadzonych przeze mnie badań są dwojakiego rodzaju: teoretyczne i praktyczne (o charakterze rekomendacji), o czym piszę w książce pt. Kształce- 
nie elit społecznych? Studia doktoranckie w Polsce jako forma i potrzeba konstruowania zapoznanego mitu.

Po pierwsze, analizując powyższe wnioski, można zwrócić uwagę na inicjacyjny walor studiów doktoranckich. Jest to jednoznaczne odniesienie do koncepcji inicjacji Mircei Eliadego (1997). Doktoranci uważają, że studia doktoranckie wywołują w ich uczestnikach zmianę. Ma ona służyć rozwojowi własnych możliwości intelektualnych, ale też rozwojowi instytucji. Są testem wprowadzającym do wspólnoty ludzi nauki, przy czym selekcja właściwych kandydatów ma miejsce po zakończeniu okresu studiów.

Zaszła zmiana we mnie jako $w$ mojej osobie plus nowych technik badawczych, nowego postrzegania świata, to, że potrafię sobie lepiej zorganizować pracę, to, że nawiazywanie kontaktów ze środowiskiem naukowym jest niezbędne, żeby móc dalej tę pracę naukowa prowadzić. Kontakty są po prostu najważniejsze, ale wiem, że bardzo łatwo można je zepsuć [D14].

W czasie czterech lat pobierania nauki doktoranci wdrażani są do akademickiego świata, w którym najważniejszymi wartościami były kiedyś dobro, prawda i porządek. Dziś dyskurs zdominowały wartości merkantylne, medialne, związane z procesami globalizacji i indywidualizacji. Jednak nie zmienia to faktu, że dopuszczane do tej wspólnoty wartości są osoby w jakiś sposób wyjątkowe, bo pokłada się w nich nadzieję i zaufanie (np. że będą kontynuować misję uniwersytetu).

Na pewno, ale to by się musiato zmienić podejście jakby spoteczeństwa ogólnie do tego, żeby to nie było tak, że studia doktoranckie są tylko takim przedszkolem dla pracy naukowej na uczelni [D7].

Dzięki studiom doktoranci przekraczają pewną granicę - tworzenia i konstruowania wiedzy, do czego muszą być w jakiś sposób predestynowani, ale też gotowi. Stąd tak ważne stają się posiadane kapitały: symboliczny, społeczny, ekonomiczny, kontrolowane przez uniwersytet. To uczelnia decyduje bowiem, kto otrzyma wsparcie finansowe, a kto będzie musiał podjąc dodatkowe zajęcia, by móc się utrzymać (co może spowodować nadmierne rozproszenie uwagi, która powinna być poświęcona rozwojowi naukowemu). Dlatego też badani doktoranci jednogłośnie deklarują, że okres studiów jest czasem wymagającym poświęcenia. Zjawisko to ma charakter egalitarny, bowiem dotyczy wszystkich, ale też może powodować poczucie łączności i zjednoczenia z innymi.

W momencie kiedy poszlam pierwszy raz na prace archeologiczne we Wrocławiu, ja byłam przerażona. Ja nigdy nie byłam na żadnej budowie, ja nie wiedziałam, jak się zachowują robotnicy, jak się zachowują inżynierowie na budowie. „Przyszła taka panienka”, myśleli, „no przyszła, no dawaj, zrobimy z nią, co chcemy”. I w tym momencie ja sobie uświadomiłam, że nieważne, kim się jest, każdy ma swój cel. Studia doktoranckie, praca, na studiach doktoranckich uświadomita 
mi, że my wszyscy jesteśmy równi. Nieważne, czy ja mam studia wyższe, a ktoś nie, my jesteśmy wszyscy tacy sami. I co jeszcze? Wtaśnie na tym pierwszym nadzorze uderzyto mnie to, że ci zwykli robotnicy, którzy wykonuja to, nie wiem, ukladaja kostkę brukową, wylewają asfalt, sa bardziej wartościowi czy sq bardziej oczytani niż np. niejeden inżynier, który by nad nimi. Więc wyksztatcenie nie świadczy o tym, że ktoś jest lepszy, a ktośjest gorszy [D14].

Po drugie, wnioski z badań mogą stać się podstawą budowania ścieżek karier doktoranckich (konstruowania programów studiów, systemu wsparcia doktorantów itp.). $\mathrm{Z}$ tego powodu warto zaprezentować także mało rozbudowane uwagi doktorantów w sprawie zmian systemu kształcenia. Jak się okazuje, doktoranci nie mają spójnej wizji studiów, który chcieliby realizować. Skupiają się na krytyce systemu czy uniwersytetu, ale nie na budowaniu pozytywnych wzorców. Nie składają propozycji przebudowy systemu studiów, nie umieją znaleźć własnych innowacyjnych rozwiązań poprawy krytykowanej instytucji.

Najgorzej ocenianym elementem studiów doktoranckich jest program studiów, zmieniany zgodnie z potrzebami i możliwościami kadrowymi, niekiedy nawet $\mathrm{z}$ roku na rok. Stanowi to dowód na przypadkowość i brak ogólnego zamysłu kształtu studiów doktoranckich w danych jednostkach, to znaczy tego, czego należy doktorantów uczyć i co może być im potrzebne w rozwoju naukowym. W przeprowadzonych rozmowach nie pojawiła się ponadto ani jedna wypowiedź wskazująca na istnienie konsultacji programu studiów z doktorantami, tak by był on atrakcyjny i po prostu - ciekawy. Zajęcia dla doktorantów i treści na nich omawiane nie mają często przełożenia na zainteresowania badawcze doktorantów, którzy muszą poświęcać czas na przygotowania do egzaminów i zaliczeńn ${ }^{11}$.

Jednym z elementów do zmiany i przedyskutowania jest system stypendiów zarówno doktoranckich, jak i pomoc materialna dla osób potrzebujących wsparcia finansowego, a także system wsparcia badań prowadzonych w ramach doktoratu oraz możliwości wyjazdów na konferencje i staże badawcze. Często wskazywaną cechą studiów doktoranckich jest niedostateczne podkreślanie misji tej formy kształcenia. Nie jest ona widoczna ani dla osób wprowadzających zmiany, ani dla tych, którzy muszą się tym zmianom podporządkować. Ma więc miejsce ciągłe balansowanie między ideami tradycyjnego uniwersytetu, opartego na szukaniu prawdy i wolności, a rynkowym podejściem do usług kształcenia oferowanych przez wyższe uczelnie. Opisywana nieokreśloność może mieć jednak bardzo negatywne skutki, bowiem tworzy się obecnie nowa grupa społeczna - be z robotn ych doktoró $\mathrm{w}^{12}$.

${ }^{11}$ Część wniosków została zaprezentowana w tekście autorki (napisanym razem z M. Dudzikową, E. Bochno, P. Grzybowskim, A. Korzeniecką-Bondar, M. Wiśniewską-Kin) pt. Młodzi badacze o swoim doświadczeniu związanym z doskonaleniem warsztatu naukowego i pisarskiego (panel dyskusyjny) (2013).

${ }^{12}$ Jest to cytat z wypowiedzi osoby badanej, a nie wsparta badaniami konkluzja. Badania OECD pokazują, że poziom bezrobocia w badanych krajach Unii Europejskiej, USA i Chin nie przekracza 
Ksztatcenie powinno być bardziej dopasowane do potrzeb rynkuczy doktorantów, czy uniwersytetów, czy potrzeb jakichś instytucji badawczych, żeby to jakby nie było tak sobie, bo później ludzie przeżywają takie, w ogóle istnieja, jakby nie mogli się pogodzić z tą sytuacją, napisat doktorat, nie ma pracy, czy nie wiem, kiedyś nie do pomyślenia, że ktoś z wyższym wyksztatceniem byt bezrobotny, a dzisiaj jakby osoby z doktoratem [D3].

Propozycją rozwiązania tego zgłaszanego przez doktorantów problemu może być traktowanie studiów doktoranckich jako inwestycji, zarówno państwa, jak i osób studiujących. Być może zatem warto do otwartej dyskusji nad modelem kształcenia uniwersyteckiego w Polsce, toczącej się od 2011 r. (a szczególnie w latach 2016-2017), wprowadzić więcej pomysłów na promocję obywatelskiego zaangażowania. Jest to związane z konstruowaną w książce nową definicją elit. Jak się okazało, sukces jednostki - doktoranta - jest wygraną tylko wtedy, gdy jest on wpisany w szerzej ujmowaną ścieżkę kariery, niekoniecznie realizowanej na uczelni czy w instytucjach badawczych (Kwiek i Antonowicz 2015). Można bowiem wskazać wiele dróg nie tylko prowadzących do doktoratu, ale i od doktoratu. Różnorodność jawi się jako siła systemu akademickiego i ma znaczenie dla rozwoju społecznego, w tym rozwoju gospodarki i jej innowacyjności, a także może pozytywnie wpływać na kształtowanie się nowych elit społecznych.

\section{Literatura}

Auriol, L., Misu, M., Freeman, R.A. (2013). Careers of Doctorate Holders: Analysis of Labour Market and Mobility Indicators. OECD. Science, Technology and Industry Working Papers. 4.

Bourdieu, P., Passeron, J.-C. (1990). Reprodukcja. Elementy teorii system nauczania. Tłum. E. Neyman. Warszawa: Wyd. Naukowe PWN.

Davenport, T.H. (2007). Zarzadzanie pracownikami wiedzy. Tłum. M. Lany. Warszawa: Wolters Kluwer Polska.

Dominicé, P. (2006). Uczyć się z życia. Biografia edukacyjna w edukacji dorostych. Wstęp O. Czerniawska. Tłum. M. Kopytowska. Łódź: Wyd. Wyższej Szkoły Humanistyczno-Ekonomicznej.

Eliade, M. (1997). Inicjacja, obrzędy, stowarzyszenia tajemne: narodziny mistyczne. Tłum. K. Kocjan. Kraków: Znak.

Fukuyama, F. (2009). Koniec historii. Tłum. T. Bieroń, M. Wichrowski. Kraków: Znak.

GUS (2016). Szkoły wyższe i ich finanse w 2015 roku. Warszawa: Główny Urząd Statystyczny.

Kola, A.M., Dudzikowa, M., Bochno, E., Grzybowski, P., Korzeniecka-Bondar, A., Wiśniewska-Kin, M. (2013). Młodzi badacze o swoim doświadczeniu związanym z doskonale-

kilku procent (ok. 5\%) osób w grupie posiadających stopień doktora (Auriol, Misu i Freeman 2013: 13-14). 
niem warsztatu naukowego i pisarskiego (panel dyskusyjny). Przegląd Badań Edukacyjnych. 1(16): 113-147.

Kola, A. M. Kształcenie elit spotecznych? Studia doktoranckie $w$ Polsce jako forma i potrzeba konstruowania zapoznanego mitu (oddany do druku).

Kwiek, M., Antonowicz, D. (2015). The Changing Paths in Academic Careers in European Universities: Minor Steps and Major Milestones. W: T. Fumasoli, G. Goastellec, B. M. Kehm (red.). Academic Work and Careers in Europe: Trends, Challenges, Perspectives (41-68). London: Springer International Publishing.

Mills Ch.W. (1961). Elita władzy. Warszawa: Książka i Wiedza.

NIK (2015). Ksztatcenie na studiach doktoranckich. Warszawa: Najwyższa Izba Kontroli. Pareto, V. (1994). Uczucia i działania: fragmenty socjologiczne. Tłum. M. Dobrowolska, M. Rozpędowska, A. Zinserling. Wybór, wstęp i red. nauk. A. Kojder. Warszawa: Wyd. Naukowe PWN.

Putnam, R. (2008). Samotna gra $w$ kręgle: upadek $i$ odrodzenie wspólnot lokalnych $w$ Stanach Zjednoczonych. Tłum. P. Sadura i S. Szymański. Przedmowa M. Ziółkowski. Warszawa: Wyd. Akademickie i Profesjonalne.

Rubacha, K. (2008). Metodologia badań nad edukacją. Warszawa: Wyd. Akademickie i Profesjonalne.

Schütze, F. (1997). Trajektorie cierpienia jako przedmiot badań socjologii interptetatywnej. Studia Socjologiczne. 1: 11-56.

Szkudlarek, T. (2012). Robotnicy wiedzy i edukacja akademicka. W: P. Żuk (red.). Wiedza, ideologia, wladza: o społecznej funkcji uniwersytetu $w$ społeczeństwie rynkowym (215-237). Warszawa: Scholar.

Żyromski, M. (2007). Teorie elit a systemy polityczne. Poznań: Wyd. Naukowe UAM.

\section{Doctoral candidates - chosen ones or losers? Conclusions from a theoretical-empirical research on doctoral studies in Poland}

ABSTRACT. In the academic year 2015/2016, there were more than 40,000 people studying for a Ph.D. in Poland. Set against the scale known from before the education boom of the 1990s, the figure is staggering. The fact that so many young people (not all of them young, as there is no age limit on education opportunities on any level) wish to be ever better educated and work their way up the academic ladder, may well be seen as a positive development. However, if public debate on the matter is anything to go by, it would seem that there are more downsides than advantages to this state of affairs: the devaluation of Master's degrees, the mass character of the education process and the absence of genuine master-disciple relationships are but few of the disadvantages. Does the university matter, does it inform students' life choices? It seemed worthwhile to get to know the answers to these questions, using the circumstances of Ph.D. students, their financial status, and the economic, social and cultural capital at their disposal, as reference points. Asking these questions gave me a pretext and a reason to undertake research in Poland as well as the best universities in the world (Harvard University, University of Oxford, Peking University and others). The survey of doctoral students, carried out between 2010 and 2013, is part of a more extensive programme concerning the education of social elites worldwide and bringing about social change. The programme 
in question comprises a variety of comparative and cultural themes: the manner in which doctoral studies are structured and conducted, the master-disciple relationship (not least in its historical aspect), the quality of education offered, social structure and its determinants. The research cited in the text comes from my book Kształcenie elit spolecznych? Studia doktoranckie $w$ Polsce jako forma i potrzeba konstruowania zapoznanego mitu [The Shaping of Social Elites? Doctoral Studies in Poland as a Form of Constructing an Obsolete Myth, and Expressing the Need for such a Myth]. The book is a complete report that covers many more problems and questions about doctoral studies' system in Poland.

KEYWORDS: PhD, PhD candidates, doctoral studies, social elites, elitist education

CYTOWANIE: Kola, A.M. (2016). Doktoranci - grupa wybrana czy przegrana? Prezentacja wniosków studium teoretyczno-empirycznego na temat studiów doktoranckich w Polsce. Nauka i Szkolnictwo Wyższe. 2(48): 175-191. DOI: 10.14746/nisw.2016.2.8. 
